\title{
THE EFFECT OF FINANCIAL LITERATURE AND SELF CONTROL ON CONSUMPTION BEHAVIOR (STUDY ON STUDENTS OF THE FACULTY OF ECONOMICS AND BUSINESS UNIVERSITAS MUHAMMADIYAH SUMATERA UTARA)
}

\author{
Maya Sari ${ }^{1}$, Nur Adilla Bahri Lubis ${ }^{2}$, Jufrizen ${ }^{3}$ \\ Faculty of Economics and Business, Universitas Muhammadiyah Sumatera Utara \\ Jl. Kapten Muktar Basri, No.3 / Tel. (061) 6624567 Medan, 20238 \\ E-mail: mayasari@umsu.ac.id
}

\begin{abstract}
The purpose of this study was to determine and analyze the effect of financial literacy on consumptive behavior of students with financial concentration in 2017 in the Management Study Program, Faculty of Economics and Business, Universitas Muhammadiyah Sumatera Utara. to find out and analyze the effect of self-control on consumptive behavior. Students with 2017 financial stambuc concentration in Management Study Program, Faculty of Economics and Business, Universitas Muhammadiyah Sumatera Utara. This study uses a quantitative research approach. The data analysis technique in this study uses multiple linear analysis techniques. The results of the study indicate that partially there is a significant effect of the Financial Literacy variable on the Consumptive Behavior of the Students of the Faculty of Economics and Business, Universitas Muhammadiyah Sumatera Utara. The results of this study conclude that partially there is a significant effect of the variable Self-Control on Consumptive Behavior in Students of the Faculty of Economics and Business, Universitas Muhammadiyah Sumatera Utara. Economics and Business Universitas Muhammadiyah Sumatera Utara.
\end{abstract}

Keywords: Financial Literacy, Self Control, Consumptive Behavior

\section{INTRODUCTION}

Entering the current era of globalization, many encourage the economic development of society in a country. As can be seen from the development of industry which has been able to provide everything that is needed by the community. The growing era of society began to compete in meeting their needs even something that is not a need will be fulfilled because of the people's desire to own or consume. If these behavioral activities occur continuously, it will become a consumptive behavior. From the results of a survey conducted on students of the Faculty of Economics and Business, Universitas Muhammadiyah Sumatera Utara, it shows that most students are more concerned with buying branded goods such as buying makeup, clothes, and buy other items to look up to date and students compete with each other to keep up with the trends. And a small number of students choose to buy books and other college supplies. In addition, the survey results show that $90 \%$ of students will increase their consumption when their income increases. And only about $10 \%$ of students choose not to increase their consumption. And some students prefer to spend their spare time hanging out with friends at cafes, or other similar places, shopping at shopping centers such as malls and other shopping centers. In addition, the survey results show that $90 \%$ of students will increase their consumption when their income increases. And only about $10 \%$ of students choose not to increase their consumption. And some students prefer to spend their spare time hanging out with friends at cafes, or other similar places, shopping at shopping centers such as malls and other shopping centers. In addition, the survey results show that $90 \%$ of students will increase their consumption when their income increases. And only about $10 \%$ of students choose not to increase their consumption. And 


\section{The Effect Of Financial Literature And Self Control On Consumption Behavior (Study On Students Of The Faculty Of Economics And Business Universitas Muhammadiyah Sumatera Utara) \\ Maya Sari, Nur Adilla Bahri Lubis, Jufrizen}

some students prefer to spend their spare time hanging out with friends at cafes, or other similar places, shopping at shopping centers such as malls and other shopping centers.

From the survey results, it is clear that there are indications of student consumptive behavior and the difficulty of students controlling themselves as well as lack of knowledge about financial literacy which causes students to have consumptive behavior among students at the Universitas Muhammadiyah Sumatera Utara, Faculty of Economics and Business. Nowadays, the phenomenon that often occurs is an existence crisis in society, especially among teenagers, they do it in various ways to try to be part of the environment. The need to be accepted and be the same as other people of the same age causes adolescents to try to follow various current attributes (Fattah et al., 2018). The attributes used by teenagers vary from the attributes used on the head to the feet, for example the use of the hijab, clothes with various fashions, tight jeans and shoes. According to research (Dikria \& Mintarti, 2016) Teenagers want to show themselves that they can also follow the updated fashion even though fashion is always changing, so that teenagers are never satisfied with what they have, causing them to consume goods and services without thinking. This consumptive behavior can continue to take root in the lifestyle of a group of teenagers, in their development they will become adults with a consumptive lifestyle if not handled. so that teenagers are never satisfied with what they have, thus causing them to consume goods and services without thinking. This consumptive behavior can continue to take root in the lifestyle of a group of teenagers, in their development they will become adults with a consumptive lifestyle if not handled. so that teenagers are never satisfied with what they have, thus causing them to consume goods and services without thinking. This consumptive behavior can continue to take root in the lifestyle of a group of teenagers, in their development they will become adults with a consumptive lifestyle if not handled.

Adolescence is at the age of 13-21 years, at this age is a period of transition and search for identity, adolescents experience a process of formation in their behavior, where adolescents seek and strive to achieve the ideal self pattern, this causes adolescents to be easily influenced by various things. things around him, both positive and negative, Maentiningsih (Chita et al., 2015). The reality that is often encountered today is the tendency of students who are teenagers to imitate the up-todate consumptive lifestyle. Student lifestyles can change, but this change is not caused by the changing needs of puberty, it is no longer parents who become models,

Students are more concerned with their pocket money to buy various branded goods to keep up with the latest trends and be recognized by their friends than to buy more important campus equipment such as lecture support books. This trend-following activity encourages students to buy used goods without thinking and makes students trapped in consumptive behavior. This consumptive behavior can be seen by students who are willing to spend money to fulfill wants, not needs. The consumptive lifestyle covers all groups of teenagers, including students. Students should fill their time by adding knowledge, skills, and expertise, as well as filling their activities with various kinds of positive activities so that they will have an orientation towards the future as humans who are beneficial to society and the nation, but campus life has formed a distinctive lifestyle among students and there has been a high level of social change that makes each individual maintain his pattern of consumption. Students who are part of teenagers, will be considered to follow the times and get a "label" that raises their self-esteem if they have bought and used goods with well-known brands (Anggreini \& Mariyanti, 2014).

According to (Astuti, 2013) consumptive behavior can be interpreted as an act of using an incomplete product, meaning that a product that has not been used by someone has used the same type of product from another brand or can be mentioned, buying goods because of a gift offered or buying a product. product because many people use the item. According to (Kanserina et al., 2015) 
Consumptive behavior is a person's behavior that is no longer based on rational considerations, materialistic tendencies, a great desire to have luxurious and excessive objects and the use of everything that is considered the most expensive and driven by all desires. to fulfill the desire for pleasure.

Consumptive behavior is the desire to consume goods that are actually less needed in excess to achieve maximum satisfaction (Tambunan, 2001). This consumptive behavior does not seem to have good benefits for the perpetrators, because in addition to draining income, it can also lead to extravagance. Consumer decision making that looks "irrational" underlies the follow-up behavior or trend. Buying something to meet needs is actually not a problem, even it has become a normal thing, as long as buying it is really intended to meet the basic needs of life or what are really needed or primary needs. In accordance with what was conveyed (Asisi, 2020) that the decision in making choices is not an easy job, because it is based on certain considerations. Therefore humans need to learn how to make choices, this is what is studied in economics. Thus, economics helps individuals to fulfill their needs properly and avoid financial losses. Consumptive behavior can be influenced by internal and external conditions of the individual. Individual decisions in consumptive behavior can be influenced by several factors, namely financial literacy, and self-control.

Financial literacy is the ability to understand financial conditions and financial concepts and to transform that knowledge appropriately into behavior. According to (Widyawati, 2012) developed 15 indicators of financial literacy that have been adapted to conditions in Indonesia, namely: (1) Looking for options in a career; (2) Understanding the factors that affect net salary; (3) Identify sources of income; (4) Explain how to achieve prosperity and meet financial goals; (5) Understanding the saving budget; (6) Understanding insurance; (7) Analyze risk, return and liquidity; (8) Evaluating investment alternatives; (9) Analyzing the effect of taxes and inflation on investment returns; (10) Analyzing the advantages and disadvantages of debt; (11) Explain the purpose of the credit track record and recognize the rights of the debtor; (12) Describe ways to avoid or correct debt problems; (13) Knowing the basic law of consumer protection in credit and debt; (14) Able to make financial records; (15) Understand the balance sheet, profit and loss statement and cash flow. The large number of people who do not understand financial literacy such as financial knowledge, causing many people to experience losses, either due to a decline in economic conditions and inflation or due to the development of an economic system that tends to be wasteful because people are increasingly consumptive. (Krishna et al.,

According to (Dikria \& Mintarti, 2016) self-control is an individual's way of controlling behavior, controlling cognition and controlling decisions. Individuals who have a high level of selfcontrol will consider in advance whether the purchase to be made is a purchase that is really needed or not. Self-control can be defined as a control of behavior. Behavioral control implies that in doing something someone considers first what is good and what is right before taking action. The higher a person's self-control, the higher the control of that person's behavior. Self-control helps achieve longterm success or higher goals to the exclusion of short-term pleasures (De Boer et al., 2015). The effect of self-control on consumptive behavior proves the truth according to (Syamsul, 2010) selfcontrol is an individual's ability to control impulses, both from within and from outside the individual.

Based on the above background and with the development of the current era, it becomes a very appropriate reason and makes the author interested in researching in a proposal article entitled "The Effect of Financial Literacy and Self-Control on Consumptive Behavior of Students of the Faculty of Economics and Business, Universitas Muhammadiyah Sumatera Utara". 
The Effect Of Financial Literature And Self Control On Consumption Behavior (Study On Students Of The Faculty Of Economics And Business Universitas Muhammadiyah Sumatera Utara)

Maya Sari, Nur Adilla Bahri Lubis, Jufrizen

\section{RESEARCH METHOD}

The research used is survey research with an explanatory research approach. The population of this study were students of the Universitas Muhammadiyah Sumatera Utara as many as 76 respondents consisting of gender, age and semester. This research starts from December 2020 - April 2021. The variables used in this study include the independent variables, namely financial literacy and self-control with the dependent variable being consumptive behavior. Determination of sampling using non-probability sampling method. The sampling technique in this study used saturated sampling. Data analysis techniques in this study include data quality tests (validity and reliability tests), classical assumption tests, multiple linear regression and hypothesis testing.

Financial Literacy According to (Krishna et al., 2010) financial literacy is a basic need for everyone to avoid financial problems. Where indicators on financial literacy used are finding choices in their careers, understanding factors that affect net salary, knowing sources of income, explaining how to achieve prosperity and meeting financial goals, understanding budget savings, understanding insurance, analyzing risk, returns and liquidity, evaluate investment alternatives, to analyze the effect of taxes and inflation on investment returns, to analyze the effect of taxes and inflation on investment taking, to explain the purpose of a credit track record and identify debtor's rights, to explain ways to avoid or correct debt problems, Know the basic laws for consumer protection in credit and debt and be able to make financial records. Self-control according to (Ghufron \& Risnawati S, 2010) is a complete fabric that is carried out by individuals to their environment. The indicators used are the ability to control behavior, the ability to control the stimulus, the ability to anticipate an event or events, the ability to interpret events or events and the ability to make decisions.

\section{RESULTS AND DISCUSSION}

Regression analysis is used to determine whether there is an influence between variables. The following is a summary of the results of simple and multiple regression analysis and path analysis.

Table 1. Results of Simple Regression Analysis

\begin{tabular}{|c|c|c|}
\hline \multirow{2}{*}{ Model } & \multicolumn{2}{|c|}{ Collinearity Statistics } \\
\hline & Tolerance & VIF \\
\hline (Constant) & & \\
\hline Financial Literacy & .981 & |1.019 \\
\hline Self-control & .981 & 1.019 \\
\hline
\end{tabular}

a. Dependent Variable: Consumptive Behavior

Source: SPSS processed data (2021)

Based on table 1, it can be seen that the independent variables, namely X1 and X2, have a VIF value within a predetermined tolerance limit (not exceeding 10), so that there is no multicollinearity in this independent variable. 
Table 2. Results of Multiple Regression Analysis

\begin{tabular}{|c|c|c|c|c|c|}
\hline \multirow[t]{2}{*}{ Model } & \multicolumn{2}{|c|}{$\begin{array}{l}\text { Unstandardized } \\
\text { Coefficients }\end{array}$} & $\begin{array}{l}\text { Standardized } \\
\text { Coefficients } \\
\end{array}$ & \multirow[t]{2}{*}{$\mathrm{T}$} & \multirow[t]{2}{*}{ Sig. } \\
\hline & $\mathrm{B}$ & Std. Error & Beta & & \\
\hline 1 (Constant) & 12,597 & 4.243 & & 2,969 & .004 \\
\hline Financial Literacy & .288 & $\mid .059$ & .434 & 4.481 & .000 \\
\hline Self-control & 377 & .057 & .604 & 6.675 & .000 \\
\hline
\end{tabular}

a. Dependent Variable: Consumptive Behavior

Source: SPSS processed data (2021)

Based on table 2, it can be seen that $\mathrm{H} 0$ is rejected if ttable is 1.992 tcount and tcount 1,992 and Ha is accepted if ttable is $1,992<$ tcount and tcount > 1.992 .

Table 3. Effect of Self-Control, Financial Literacy on Consumptive Behavior

\begin{tabular}{|l|l|l|l|l|l|}
\hline Model & $\mathrm{R}$ & R Square & $\begin{array}{c}\text { Adjusted R } \\
\text { Square }\end{array}$ & $\begin{array}{c}\text { Std. Error of } \\
\text { the Estimate }\end{array}$ & $\begin{array}{c}\text { Durbin- } \\
\text { Watson }\end{array}$ \\
\hline 1 & & & &
\end{tabular}

a. Predictors: (Constant), Self-Control, Financial Literacy

b. Dependent Variable: Consumptive Behavior

Source: SPSS processed data (2021)

Based on table 3, it can be seen that the results of the regression calculation can be seen that the coefficient of determination ( $\mathrm{R}$ square) obtained is 0.405 , this result means that $40.5 \%$ of the variable Consumptive Behavior can be explained by the variable Financial Literacy, Self-Control while the rest is $59.5 \%$ is explained by other variables not examined.

\section{CONCLUSION}

From the research conducted, the following results were found: 1) the results of this study concluded that partially there was a significant effect of the Financial Literacy variable on Consumptive Behavior in Students of the Faculty of Economics and Business, Universitas Muhammadiyah Sumatera Utara. 2) The results of this study conclude that partially there is a significant effect of the self-control variable on consumptive behavior in students of the Faculty of Economics and Business, Universitas Muhammadiyah Sumatera Utara. 3) The results of this study conclude that there is a simultaneous and significant effect of Financial Literacy and Self-Control on Consumptive Behavior in Students of the Faculty of Economics and Business, Universitas Muhammadiyah Sumatera Utara.

From the results of this study, suggestions can be given, first for students to apply the knowledge gained during education such as microeconomics, macroeconomics, monetary, and others into daily activities, such as saving, planning and managing finances so as to reduce behavior. excessive consumption. Second, students are expected to be able to control themselves in terms of consumptive behavior, and buy goods according to the needs and benefits provided. Third, for future researchers, further research can be carried out using other variables, with a larger number of students and different research locations. 
The Effect Of Financial Literature And Self Control On Consumption Behavior (Study On Students Of The Faculty Of Economics And Business Universitas Muhammadiyah Sumatera Utara)

Maya Sari, Nur Adilla Bahri Lubis, Jufrizen

\section{REFERENCE}

Andjani, S. (1991). Efektifitas Teknik Kontrol Diri pada Pengendalian Kemarahan. Jurnal Psikologi, $1,54-59$.

Anggreini, R., \& Mariyanti, S. (2014). Hubungan Antara Kontrol Diri dan Perilaku Konsumtif Mahasiswi Universitas Esa Unggul. Jurnal Psikologi Esa Unggul, 12(01), 34-42.

Asisi, I. (2020). Pengaruh Literasi Keuangan, Gaya Hidup Dan Pengendalian Diri Terhadap Perilaku Konsumtif Mahasiswa Prodi Manajemen Fakultas Ekonomi Universitas Pasir Pengaraian. HIRARKI: Jurnal Ilmiah Manajemen Dan Bisnis, 2(1), 107-118.

Astuti, E. D. (2013). Perilaku konsumtif Dalam Membeli Barang Pada Ibu Rumah Tangga Di Kota Samarinda. Psikoborneo: Jurnal Ilmiah Psikologi, 1(2), 79-83.

Atkinson, A., \& Messy, F.-A. (2012). Measuring financial literacy: results of the OECD/International Network on Financial Education (INFE) Pilot study (No. 15; OECD Working Papers on Finance, Insurance and Private Pensions). https://doi.org/10.1787/5k9csfs90fr4-en.

Bhushan, P., \& Medury, Y. (2013). Financial Literacy and its Determinants. International Journal of Engineering, Business and Enterprise Applications (IJEBEA), 4(2), 155-160.

Chen, H., \& Volpe, R. P. (1998). An Analysis of Personal Financial Literacy among College Students. Financial Services Review, 7(2), 107-128. https://doi.org/10.1016/S10570810(99)80006-7

Chita, R. C. M., David, L., \& Pali, C. (2015). Hubungan Antara Self-Control Dengan Perilaku Konsumtif Online Shopping Produk Fashion Pada Mahasiswa Fakultas Kedokteran Universitas Sam Ratulangi Angkatan 2011. EBiomedik, 3(1), 297-302. https://doi.org/10.35790/ebm.3.1.2015.7124

De Boer, B. J., Van Hooft, E. A. J., \& Bakker, A. B. (2015). Self-Control At Work: Its Relationship With Contextual Performance. Journal of Managerial Psychology, 30(4), 406-421. https://doi.org/10.1108/JMP-08-2012-0237

Dewi, N., Rusdarti, \& Sunarto, S. (2017). Pengaruh Lingkungan Keluarga , Teman Sebaya, Pengendalian Diri dan Literasi Keuangan Terhadap Perilaku Konsumtif Mahasiswa. Journal Of Economic Education, 6(1), 29-35.

Dikria, O., \& Mintarti, S. U. (2016). Pengaruh Literasi Keuangan Dan Pengendalian Diri Terhadap Perilaku Konsumtif Mahasiswa Jurusan Ekonomi Pembangunan Fakultas Ekonomi Universitas Negeri Malang Angkatan 2013. Jurnal Pendidikan Ekonomi, 9(2), 128-139.

Fattah, F. A., Indriayu, M., \& Sunarto. (2018). Pengaruh Literasi Keuangan dan Pengendalian Diri Terhadap Perilaku Konsumtif Siswa SMA Muhammadiyah 1 Karanganyar. Jurnal Pendidikan Bisnis Dan Ekonomi, 4(1), 11-21.

Fudyartanta, K. (2012). Psikologi perkembangan. Yogyakarta: Pustaka Pelajar.

Gailliot, M. T., Baumeister, R. F., DeWall, C. N., Maner, J. K., Plant, E. A., Tice, D. M., Brewer, L. E., \& Schmeichel, B. J. (2007). Self-control relies on glucose as a limited energy source: willpower is more than a metaphor. Journal of Personality and Social Psychology, 92(2), 325. 
Ghozali, I. (2013). Aplikasi Analisis Multivariete dengan Program IBM SPSS 23 (VIII). (8th ed.). Semarang: Badan Penerbit Universitas Diponegoro.

Ghufron, M. N., \& Risnawati, R. (2012). Teori-Teori Psikologi Cetakan III. Yogyakarta: Ar-Ruzz Media.

Ghufron, M. N., \& Risnawita S, R. (2010). Teori-teori psikologi. Ar-Ruzz Media.

Gunawan, A., Pulungan, D. R., \& Koto, M. (2018). Peran Literasi Keuangan Pada Kemampuan Pengelolaan Keuangan Untuk Persiapan Masa Pensiun Secara Mandiri (Studi Kasus Pada Dosen Fakultas Ekonomi \& Bisnis UMSU).

Harnum, D. (2012). Hubungan antara Teknik Kontrol Diri dengan Kecenderungan Perilaku Konsumtif Mahasiswi di Ma'had Sunan Ampel Al-Aly Universitas Islam Negeri (UIN) Maulana Malik Ibrahim Malang. Skripsi Diterbitkan. Malang: Fpsi UIN MALIKI.

Imawati, I., Susilaningsih, \& Ivada, E. (2013). Pengaruh Financial Literacy Terhadap Perilaku Konsumtif Remaja pada Program IPS SMA Negeri 1 Surakarta Tahun Ajaran 2012/2013. Jupe UNS, 2(1), 48-58.

Juliandi, A., \& Manurung, S. (2014). Metodologi Penelitian Bisnis, Konsep dan Aplikasi: Sukses Menulis Skripsi \& Tesis Mandiri. Umsu Press.

Juliandi, A., Irfan, I., \& Manurung, S. (2015). Metodologi Penelitian Bisnis Konsep Dan Aplikasi. UMSU Press.

Khaddafi, M. ., Aryani, R. A., \& Heikal, M. . (2021). THE EFFECT OF FINANCIAL KNOWLEDGE AND PERSONAL NET INCOME ON THE FINANCIAL BEHAVIOR OF MALIKUSSALEH UNIVERSITY EMPLOYEES WITH LOCUS OF CONTROL AS MODERATING VARIABLES. International Journal of Economic, Business, Accounting, Agriculture Management and Sharia Administration (IJEBAS), 1(1), 1-13. https://doi.org/10.54443/ijebas.v1i1.1

Kanserina, D., Haris, I. A., \& Nuridja, I. M. (2015). pengaruh literasi ekonomi dan gaya hidup terhadap perilaku konsumtif mahasiswa jurusan pendidikan ekonomi universitas pendidikan ganesha tahun 2015. Jurnal Pendidikan Ekonomi Undiksha, 5(1).

Kemdikbud, B. (2012). Survei Internasional PISA (Programme for International Student Assessment). Puspendik di tulis pada.

Krishna, A., Rofaida, R., \& Sari, M. (2010). Analisis tingkat literasi keuangan di kalangan mahasiswa dan faktor-faktor yang mempengaruhinya (Survey pada Mahasiswa Universitas Pendidikan Indonesia). Proceedings of The 4th International Conference on Teacher Education, 4(1), 552560.

Lestarina, E., Karimah, H., Febrianti, N., Ranny, R., \& Herlina, D. (2017). Perilaku Konsumtif di Kalangan Remaja. JRTI (Jurnal Riset Tindakan Indonesia), 2(2), 1-6. https://doi.org/10.29210/3003210000

Lina, L., \& Rosyid, H. F. (1997). Perilaku konsumtif berdasarkan locus of control pada remaja putri. Psikologika: Jurnal Pemikiran Dan Penelitian Psikologi, 2(4), 5-14. 
The Effect Of Financial Literature And Self Control On Consumption Behavior (Study On Students Of The Faculty Of Economics And Business Universitas Muhammadiyah Sumatera Utara)

Maya Sari, Nur Adilla Bahri Lubis, Jufrizen

Lusardi, A., \& Mitchell, O. S. (2011). Financial literacy around the world: an overview. National Bureau of Economic Research Working Paper Series, w17107.

Mendari, A. S., \& Kewal, S. S. (2013). Tingkat Literasi Keuangan Di Kalangan Mahasiswa STIE MUSI. Jurnal Economia, 9(2), 130-140. https://doi.org/10.21831/economia.v9i2.1804

Mutrofin, L., \& Haryono, A. (2018). Pengaruh Status Sosial Ekonomi Orang Tua, Kontrol Diri, Dan Respon Pada Iklan Terhadap Pola Perilaku Konsumtif Mahasiswa Fakultas Ekonomi, Jurusan Ekonomi Pembangunan, Universitas Negeri Malang. Jurnal Pendidikan Ekonomi, 11(1), 5662.

Nidar, S. R., \& Bestari, S. (2012). Personal Financial Literacy Among University Students (Case Study at Padjadjaran University Students, Bandung, Indonesia). World Journal of Social Sciences, 2(4), 162-171.

Noor, J. (2016). Metodologi Penelitian: Skripsi, Tesis, Disertasi dan Karya Ilmiah. Jakarta: Kencana Prenada Media Group.

Pulungan, D. R., \& Febriaty, H. (2018). Pengaruh Gaya Hidup dan Literasi Keuangan Terhadap Perilaku Konsumtif Mahasiswa. Jurnal Riset Sains Manajemen, 2(3), 103-110. https://doi.org/10.5281/zenodo.1410873

Rasyid, R. (2012). Analisis Tingkat Literasi Keuangan Mahasiswa Program Studi Manajemen Fakultas Ekonomi Universitas Negeri Padang. Jurnal Kajian Manajemen Bisnis, 1(2), 91-106. https://doi.org/10.24036/jkmb.477800

Sari, R. A. (2019). Pengaruh Gaya Hidup Brand Minded dan Kontrol Diri Terhadap Perilaku Konsumtif Pada Dewasa Awal. Psikoborneo: Jurnal Ilmiah Psikologi, 7(1), 37-46.

Setyawati, N. (2010). Hubungan antara Harga Diri dengan Perilaku Konsumtif pada Remaja. Universitas Muhammadiyah Surakarta.

Sugiyono, P. D. (2009). Metode Penelitian Kuantitatif Kualitatif Dan R \&D, Alfabeta. Denzin, NK, \& Lincoln, S. Yvonna.

Sugiyono. (2017). Metode Penelitian Bisnis: Pendekatan Kuantitatif, Kualitatif, Kombinasi, dan R\&D. Alfabeta.

Sukari, S., Larasati, T. A., Mudjijono, M., \& Susilantini, E. (2013). Perilaku Konsumtif SMA di Daerah Istimewa Yogyakarta. Yogyakarta: Balai Pelestarian Nilai Budaya.

Suliyanto, S. (2017). Metode Penelitian Kuantitatif.

Sumartono, \& Djabar, H. B. (2002). Terperangkap dalam iklan: meneropong imbas pesan iklan televisi. Alfabeta.

Syamsul, B. T. (2010). Psikologi Pendidikan Berbasis Analisis Empiris Aplikatif. Kencana.

Tambunan, T. (2001). Perekonomian Indonesia: teori dan temuan empiris. Ghalia Indonesia.

Ursia, N. R., Siaputra, I. B., \& Sutanto, N. (2013). Prokrastinasi Akademik Dan Self-Control Pada 


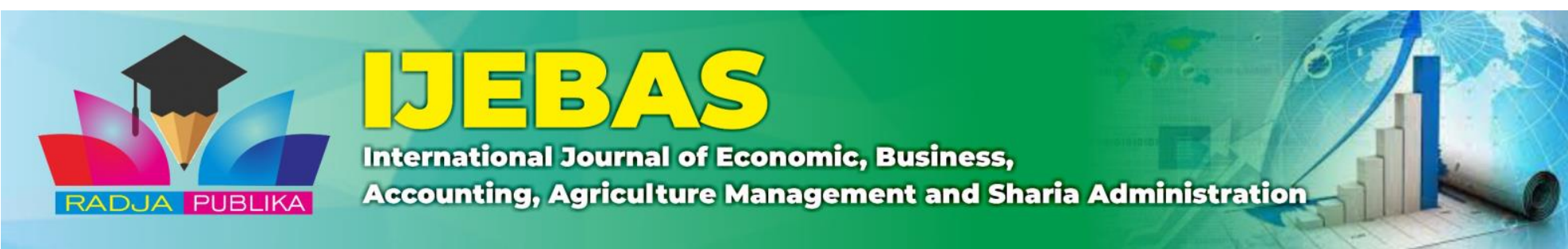

Mahasiswa Skripsi Fakultas Psikologi Universitas Surabaya-Academic Procrastination And Self-Control In Thesis Writing Students Of Faculty Of Psychology, Universitas Surabaya. Makara Seri Sosial Humaniora, 17(1), 1-18.

Widdowson, D., \& Hailwood, K. (2007). Financial literacy and its role in promoting a sound financial system. The Reserve Bank of New Zealand Bulletin, 70(2), 37-47.

Widyawati, I. (2012). Faktor-faktor yang mempengaruhi literasi finansial mahasiswa fakultas ekonomi dan bisnis Universitas Brawijaya. Assets: Jurnal Akuntansi Dan Pendidikan, 1(1), 8999.

Zulkarnain, S. (2002). Hubungan Kontrol Diri dengan Kreativitas Pekerja. 1-18 
Volumes 1 No 2 (2021)

The Effect Of Financial Literature And Self Control On Consumption Behavior (Study On Students Of The Faculty Of Economics And Business Universitas Muhammadiyah Sumatera Utara)

Maya Sari, Nur Adilla Bahri Lubis, Jufrizen 